\title{
STUDY ON FOOD QUALITY AND SAFETY MANAGEMENT BASED ON HOTEL MANAGEMENT
}

\author{
- Short communication -
}

Zengye $\mathrm{Shi}^{1}$

\begin{abstract}
Qingdao Hotel Management Vocational and Technical College, Qingdao, Shandong, 266100, China.
\end{abstract}

\begin{abstract}
In recent years, with the frequent occurrence of food safety problems, people have begun to pay attention to food safety, especially the food safety of hotels. This paper proposed a Hazard Analysis and Critical Control Point (HACCP) management system to analyze food safety issues of hotels in order to improve the food quality and safety in hotel management. Through the practical application of the HACCP management system in the hotel catering industry, it was found that the amount of bacteria greatly reduced and the pass rate of tableware disinfection increased significantly in the hotel's food processing links, while customer satisfaction greatly improved. Therefore, the HACCP management system had great applicability in improving the food quality and safety of hotels.
\end{abstract}

Keywords: hotel catering industry; food safety management; control system; HACCP

\section{INTRODUCTION}

In recent years, with the improvement of people's living standards, the rising consumption levels and the development of the tourism industry, hotels have become integral parts in cities. Food safety management was no doubt the most basic and important link in hotel management ( $\mathrm{Ccb}$ et al., 2014). In the 1990s, with the solution of the problem of food and clothing in China, food safety problems began to change from quantity safety problems to quality safety ones. A large number of food safety problems, such as "melamine" (2008), "Sudan Red" event (2005), "clenbuterol" event (2006), "waste oil" event (2010), occurred and brought a series of negative effects to the hotel industry, seriously endangering the human life safety, causing a wide range of social concern and panic (Klein et al., 2012).

The Hazard Analysis and Critical Control Point (HACCP) system was an internationally recognized important component of food safety management practices, which could be applied in all stages of the food supply chain (Wallace, 2014) in the global food industry. It was a systematic approach to identify, assess and control the production process of a particular kind of food (Wallace et al., 2014) which existed in all aspects of food production and sales, including purchase, transportation, storage, production and selling, serving a role of protecting the safety of food in all links of the management activities (Deepananda et al, 2010). Tsola et al. (2008) found that the HACCP system could effectively reduce the final yield of microorganisms during the slaughtering process by studying the modernization of poultry slaughterhouses and food safety management systems. European countries, the United States and other countries introduced laws and regulations on HACCP, enforcing the HACCP system in food enterprises, so as to achieve the purpose of ensuring food quality and safety (Bilska et al., 2014). Qi (2014) controlled the central kitchen with the HACCP system, which provided reference for the application and development of HACCP in the hotel catering industry. This paper studied the practicality of the HACCP system in hotel food quality and safety management and established a food safety management system suitable for hotel catering enterprises. It was proved that the HACCP management system could effectively improve

${ }^{1}$ Corresponding author. E-Mail address: shizengye@yahoo.com 
the food safety of hotels, with good prospects

\section{MATERIALS AND METHODS}

\section{Establishment of the hotel HACCP system}

Though the HACCP system has not yet been widely applied in China, large-scale catering enterprises have begun to realize its importance. Taking a hotel as an example, this paper established the HACCP system to make some suggestions for the practical application of the system in the catering industry.

\section{Establishment of the HACCP team}

Firstly, an HACCP team was established for the hotel and the team members needed to be familiar with the processing flow including the purchasing, transportation and storage of raw materials and learn about the relevant food safety knowledge. The team members also needed to work together to ensure that the system could operate efficiently.

\section{Analysis of food hazard management}

The physical, chemical and biological hazards that may exist in the collection, storage, transportation and processing of raw materials of different foods were studied and the existing hazards were listed. Afterwards, the causes and ways of these hazards were analyzed in detail (Carbonera et al, 2011).

\section{Purchase process}

Since food purchasing hazards are mainly from bacteria, pesticides, gravel and other pollution, a unified purchasing system should be established. Through the purchasing comparison, appropriate suppliers were selected. Meanwhile, certificate and raw material inspection were carried out rigorously to ensure the quality and safety of raw materials.

\section{Raw material storage}

In the food storage process, there were more harm links. For example, storage sites did not meet the safety standards, indoor temperature and humidity were not adjusted to the appropriate state, etc. Therefore, food needs to be stored in a space that reaches the safety environment standards.

\section{Raw material roughing and cooking}

The hazards of roughing are mainly reflected in the low safety awareness of the processing workers and improper cleaning of the processing equipment. Specifically, in the cooking process, required temperature and for development.

time are failed to be met. Therefore, in the processing process, knives and other tableware should be kept clean and safe and the safety awareness of the roughing operators should be trained. Besides, according to different types of food, the temperature and time of cooking are controlled.

\section{Dishing up}

The hazards in the dishing up process mainly come from the improper operations of the staffs and the palletizing equipment. Both poor safety awareness of operators and unhealthy equipment can lead to pollution. Hence, the hygiene condition of the equipment should be strictly monitored and the health condition and hygienic practices of employees should be controlled through SSOP.

\section{Key control of the hotel HACCP}

\section{Critical control points and limits}

Through control measures, the hazards in the critical control points of a link in the production and transportation process can be minimized. The judgment and limits of the critical control points of all links in the hotel are shown in Table 1.

Monitoring measures and corrective measures for critical control points

The monitoring of key control points was the most important part of the HACCP system (Yang et al., 2009). And the role of the establishment of monitoring measures for critical control points is to monitor whether the key control points are out of control.

In the process of raw material storage, the hotel staffs need to carefully check the temperature of the freezer as well as the storage time of the food at room temperature at each meal.

In the disinfection process, the disinfectioner needs to record the name, concentration and disinfection time of the disinfectant used for disinfection each time.

In the cooking process, the food center temperature must be strictly controlled to reach above $80^{\circ} \mathrm{C}$ and the cooking time should be appropriate. For those foods whose cooking temperature and time do not reach the limits, they should be reprocessed or disposed. In the tableware disinfection process, a specially-assigned staff needs to record the 
name, concentration and disinfection time of the disinfectant used each time. Besides, unqualified equipment must not be used.

\section{Establishment and verification of HACCP procedures}

An HACCP plan file is established to record the critical control points, key limits and corrective measures. In the HACCP plan operation, whether the records are detailed and complete should be checked. The data needs to be backed up regularly for tracking studies. In the implementation process of the hotel HACCP system, scientific and complete procedures are established to record various data so as to ensure the effective implementation of CCP. Relevant records are reviewed monthly and unqualified employees are retrained after education. Meanwhile, since a large number of daily data monitoring issues are involved in the implementation process of the hotel HACCP system, effective rules and regulations should be established to ensure the correctness and traceability of the data information so as to achieve the purpose of eliminating the potential harm from the HACCP system. The local health department conducts a hygienic inspection of the hotel every month and checks whether it is controllable in accordance with the operation of the key control points. By comparing the deviations of the operation with and without applying the HACCP system, changes in health issues are checked.

According to Table 1, it can be concluded that raw material storage, roughing, cooking and loading tables are key control points. In this study, the hotel raw material roughing and the total number of colonies during cooking and tableware disinfection safety were tested, and the qualified rate of food temperature before and after HACCP was analyzed in 2015 and 2016. Then, the HACCP system was analyzed by customer satisfaction.

Table 1. Judgment and limits of critical control points

\begin{tabular}{|c|c|c|}
\hline Process & Judgment of critical control points & Limits of critical control points \\
\hline $\begin{array}{l}\text { Raw material } \\
\text { procurement }\end{array}$ & $\begin{array}{l}\text { For the pesticide hazard in the } \\
\text { procurement process, since it can be } \\
\text { reduced by selecting a good supplier, it is } \\
\text { not a critical control point. }\end{array}$ & \\
\hline $\begin{array}{l}\text { Raw material } \\
\text { storage }\end{array}$ & $\begin{array}{l}\text { For the cross-contamination between raw } \\
\text { materials in the raw material storage } \\
\text { process, since it is inevitable and can } \\
\text { cause deterioration due to improper } \\
\text { storage, which can do serious harm to } \\
\text { food safety, it is a critical control point. }\end{array}$ & $\begin{array}{l}\text { Different foods need to be separated for } \\
\text { storage ( usually at } 0-5 \text { }{ }^{\circ} \text { Cor low } \\
\text { temperature refrigeration and } 25^{\circ} \mathrm{C} \text { for room } \\
\text { temperature refrigeration) and raw and } \\
\text { cooked food should be separated. }\end{array}$ \\
\hline Roughing & $\begin{array}{l}\text { For the roughing process, since SSOP can } \\
\text { be used to regulate the staffs in the } \\
\text { process, it is a critical control point. }\end{array}$ & $\begin{array}{l}\text { Raw materials can not be exposed at room } \\
\text { temperature for more than three hours, and } \\
\text { employees need to strictly abide by the health } \\
\text { standards and carry out disinfection on the } \\
\text { food and equipment. }\end{array}$ \\
\hline Cooking & $\begin{array}{l}\text { In the cooking process, if temperature is } \\
\text { not appropriate, it can affect the edible } \\
\text { safety and there is no subsequent step } \\
\text { that can control it within acceptable } \\
\text { limits. So, it is a critical control point. }\end{array}$ & $\begin{array}{l}\text { The center temperature of the dishes should } \\
\text { be kept above } 80^{\circ} \mathrm{C} \text { for } 10 \text { seconds to ensure } \\
\text { the safety of the food. }\end{array}$ \\
\hline Dishing up & $\begin{array}{l}\text { For the dishing up process, since SSOP } \\
\text { can be used to effectively monitor } \\
\text { employees in this process, it is a critical } \\
\text { control points. }\end{array}$ & $\begin{array}{l}\text { Operators need to undergo physical } \\
\text { examination on time; before operation, the } \\
\text { operators should complete disinfection } \\
\text { strictly; the tableware must also be } \\
\text { disinfected in accordance with national } \\
\text { standards before they are used, following } \\
\text { GMP and SSOP strictly. }\end{array}$ \\
\hline
\end{tabular}




\section{Detection methods of HACCP system}

Methods used were:

(1) Colony detection method. We investigated the average number of colonies in fifty sets of tablewares during the roughing and cooking processes of the hotel before the implementation of the HACCP system and 1, 3, 5, 7 and 9 months after its implementation. The method of colony detection is the plate count method (Huang et al., 2014).

(2) Tableware disinfection pass rate. Before the implementation of the system, we drawn out 100 sets of tableware for disinfection pass rate recording, which was then performed once every month.

\section{RESULTS AND DISCUSSION}

The total number of colonies before and after the implementation of the system

From the fifty sets of tablewares tested it was found that the average colony number was always significantly reduced, with statistical significance ( $p<0.01)$, as shown in Figure 1.

\section{Tableware disinfection pass rate}

It can be seen that the pass rate of tableware disinfection increased significantly after the HACCP system was applied, as shown in figure 2.

\section{Comparison of temperature pass rate}

The purchasing department distributes food materials to the hotel's restaurant. Since different food materials have different requirement on temperature, the restaurant will conduct a uniform inspection of the

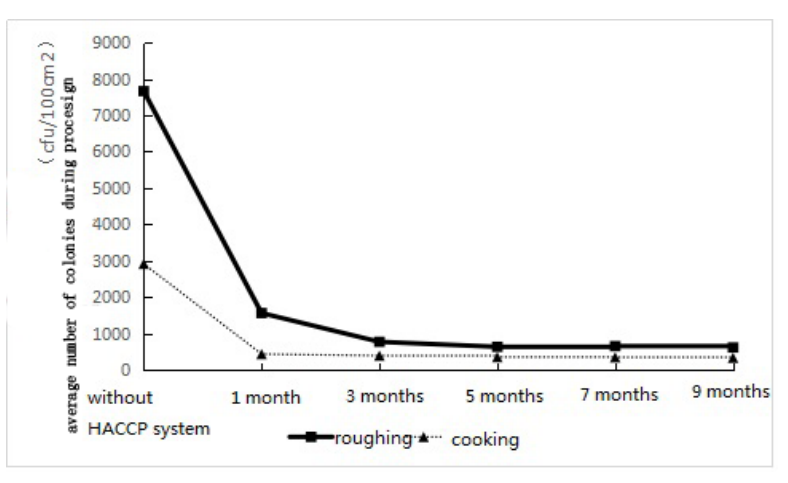

The pass rate was calculated according to the following formula: pass rate $=$ number of qualified utensils / total number of utensils (\%).

(3) Temperature pass rate. After receiving the food materials sent from the warehouse, the hotel first needed to check whether there were food materials whose temperature was not up to standard in the transportation process, according to the following equation: pass rate $=$ number of qualified food ingredients / total number of ingredients (\%).

Statistical analysis: statistical analysis was performed using SAS6.12 software. The experimental data were expressed as mean \pm standard deviation $(\mathrm{x} \pm \mathrm{s})$. Group differences were compared using one-way ANOVA.

temperature of the food materials after receiving them, which reflects the temperature control of food materials during storage and transportation to some extent. During the year in which the HACCP system was implemented, the pass rate of the temperature of the food materials from the warehouse to the restaurant was also significantly higher, as shown in figure 3 .

\section{Comparison of customer satisfaction}

During the hotel's implementation of the HACCP system, we recorded the amount of complaints per month. Compared with the same period last year, the amount of complaints greatly reduced. Ten months after the implementation of the system, the amount of customer complaints fell to 0, suggesting that the system had a significant effect in reducing customer complaint rates.

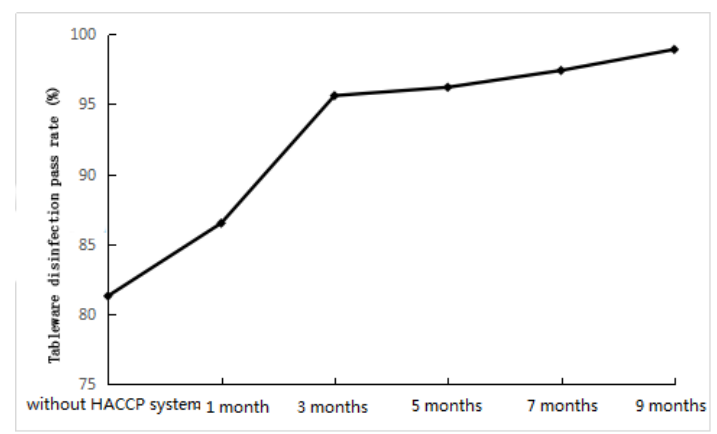


Figure 1. Total number of colonies during roughing and cooking

Figure 2. Tableware disinfection pass rate

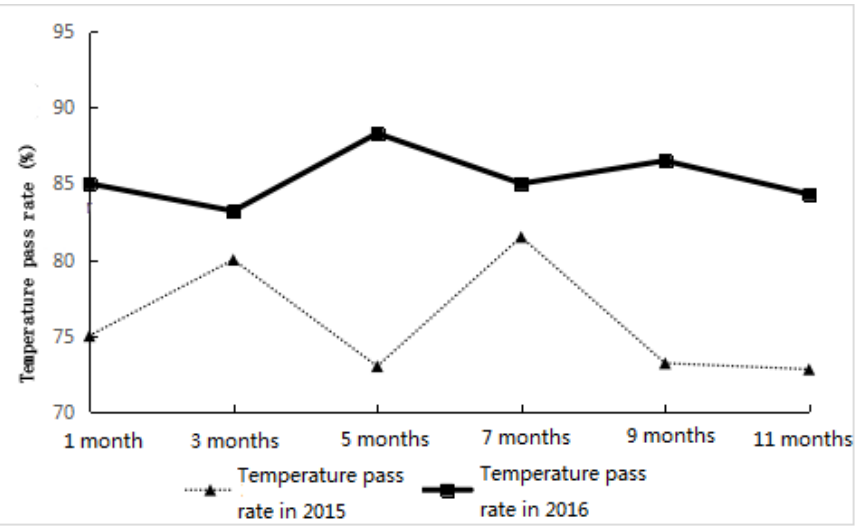

Figure 3. Comparison of temperature pass rate between 2015 and 2016

\section{CONCLUSION}

In this study, by applying the HACCP system to a hotel, the number of colonies during processing greatly reduced, the pass rate of tableware disinfection rose and the pass rate of temperature of the food materials to the restaurant went up. Meanwhile, customer satisfaction was getting much better. In conclusion, the HACCP system played a huge role on the hotel's food quality and safety management and was an innovation of the food safety supervision system as well as an effective way to ensure food safety. In the future, the HACCP system will be more widely used in the management of the hotel catering industry, as a fundamental solution to the hotel food industry food safety issues

\section{REFERENCES}

1. Bilska A, Kowalski R. (2014). Food quality and safety management. Logforum, 10(3):351-361.

2. Carbonera N, Cappelletti B M, Santo M L P E. (2011). ISO 22000/HACCP Associated with the Presence of Microorganisms in the Processing of Tilapia ( Oreochromis niloticus ) Fillets. Quality Assurance Journal, 14(3-4):50-60.

3. Deepananda H, Spencer H. (2010). Barriers to HACCP implementation: evidence from the food processing sector in Ontario, Canada. Agribusiness, 26(2):265-279.

4. Gomes, C.C.B., Lemos, G.F.C., Silva, M.C., Hora, I.M.C. and Cruz, A.G. (2014). Training of Food Handlers in a Hotel: Tool for Promotion of the Food Safety. Journal of Food Safety, 34(3):218-223.

5. Huang T, You L, Yong-Hua D U, et al. (2014). Inhibiting Effects of By-products fromCinnamomumlongepaniculatum Oil on Pathogenic Bacteria Causing Skin Infection. Journal of Sichuan Agricultural University, 32(1):53-58.

6. Klein K. Qiao, Guanghua, Ting Guo and K. K. Klein. (2012). Melamine and Other Food Safety and Health Scares in China: Comparing Households With and Without Children. Food Control, 26: 378-386.

7. Qi C. (2014). Establish Central Kitchen under HACCP Control in Food and Beverage Industry to Ensure Food Safety and Hygiene. EDP Sciences, 03005.

8. Schmidt R H, Newslow D. (2016). Hazard Analysis Critical Control Points (HACCP) Principle 1: Conduct a Hazard Analysis. Food Safety Handbook, e39-e39.

9. Tsola E, Drosinos E H, Zoiopoulos P. (2008). Impact of poultry slaughter house modernisation and updating of food safety management systems on the microbiological quality and safety of products. Food Control, 19(4):423-431.

10. Varzakas T H, Arvanitoyannis I S. (2008). Application of ISO22000 and comparison to HACCP for processing of ready to eat vegetables: Part I. International Journal of Food Science \& Technology, 43(10):1729-1741.

11. Wallace C A. (2014). Food Safety Assurance Systems: Hazard Analysis and Critical Control 
Point System (HACCP): Principles and Practice. Encyclopedia of Food Safety, 226-239.

12. Yang Z Z, Shi H, Wang Y M, et al. (2009). An application of hazard analysis and critical control points system on vector control in the "5.12" earthquake epicenter in Yingxiu town. Chinese Journal of Vector Biology \& Control, 4(2):221-225. 